\title{
Analisis Framing Kegiatan Keislaman Joko Widodo Melalui Portal Berita Setkab.go.id dalam Menjawab Isu Jokowi Antiislam Periode Oktober 2014-Juli 2018
}

\author{
Farikha Rachmawati ${ }^{1}$, Rachmat Kriyantono, dan Antoni ${ }^{3 *}$ \\ ${ }^{1,2,3}$ Universitas Brawijaya \\ E-mail: riikhaa@gmail.com¹, rachmat_kr@ub.ac.id ${ }^{2}$,ant_kom@ub.ac.id ${ }^{3 *}$ \\ *corresponding author
}

\author{
Keywords: \\ government public relations, \\ framing analysis, Islamic \\ communication, issue \\ management, press release
}

\begin{abstract}
The issue of President Jokowi is against Islam and doing criminalization of ulama was a topic of discussion which was often discussed even before being sworn in on October 20, 2014. The Cabinet Secretariat as the Government Public Relations released a release on Jokowi's activities through setkab.go.id which was the most complete news portal related to presidential activities. This study wanted to find out how the press release media presented information regarding Jokowi's Islamic activities.

This research is a qualitative research that focuses on the selection of words in the coverage of Jokowi's Islamic activities constructed by Public Relations of the Cabinet Secretariat. The data collection technique uses the documentation method in the form of news articles setkab.go.id news about Islamic Jokowi's Islamic activities. The researcher found three major topics discussed in the coverage, namely gathering with Islamic leaders and Islamic boarding schools, the government's actions to make the national santri day and Hajj policies, as well as commemorating Islamic holidays.

The author uses data framing analysis with Robert N. Entman's framing. Based on the results of the framing analysis conducted on internal media public relations setkab.go.id in the period October 2014 to July 2018 regarding Jokowi's Islamic reporting, researchers found that setkab.go.id always tried to display a positive frame on the government's performance in dispelling negative issues about Jokowi against Islam.
\end{abstract}

\begin{abstract}
ABSTRAK
Isu Presiden Jokowi antiislam dan melakukan kriminalisasi ulama menjadi buah bibir yang seringkali diperbincangkan bahkan sebelum dilantik pada 20 Oktober 2014. Sekretariat Kabinet sebagai Humas Pemerintah menampilkan release tentang kegiatan Jokowi melalui setkab.go.id yang merupakan portal berita terlengkap terkait kegiatan kepresidenan. Penelitian ini ingin mengetahui bagaimana press release media menampilkan informasi terkait kegiatan keislaman Jokowi.

Penelitian ini merupaka penelitian kualitatif yang berfokus pada pemilihan kata-kata dalam pemberitaan tentang kegiatan keislaman Jokowi yang dikonstruksi oleh Humas Sekretariat Kabinet. Teknik pengumpulan data menggunakan metode dokumentasi berupa artikel pemberitaan portal berita setkab.go.id tentang kegiatan keislaman Presiden Jokowi. Peneliti menemukan tiga topik besar yang dibahas dalam pemberitaan tersebut yaitu kegiatan silaturahmi dengan tokoh-tokoh islam dan pondok pesantren, tindakan pemerintah membuat hari santri nasional dan kebijakan haji, serta peringatan hari-hari besar islam.

Penulis menggunakan analisis data framing dengan teknik model Robert N. Entman. Berdasarkan hasil analisis framing yang telah dilakukan, peneliti
\end{abstract}


menemukan bahwa setkab.go.id selalu berupaya menampilkan bingkai positif terhadap kinerja pemerintah dalam menghalau isu negatif tentang Jokowi yang antiislam.

Copyright (C) 2019 Channel Jurnal Komunikasi. All right reserved.

\section{PENDAHULUAN}

Isu Antiislam tidak lepas dari pemberitaan tentang Joko Widodo di media online. Fenomena tersebut mendasari peneliti untuk mengetahui konstruksi yang dilakukan portal berita sekretariat kabinet terhadap sosok Jokowi sebagai pemimpin yang dikatakan antiislam. Adapun tujuan dari penelitian ini adalah untuk melihat isu apa yang ditonjolkan melalui portal berita setkab.go.id dalam membingkai sosok Jokowi sebagai pemimpin yang pro islam. Secara akademis, manfaat analisis framing dalam penelitian kehumasan berguna untuk mengetahui cara pemerintah memposisikan diri dalam sebuah situasi tertentu, dalam hal ini terkait isu keislaman jokowi. Manfaat kedua adalah untuk melakukan evaluasi pesan yang disampaikan oleh pemerintah. Secara praktis, analisis framing bermanfaat bagi humas pemerintah untuk menyusun pesan yang dapat diterima oleh publik dan menghadirkan citra positif bagi pemerintah.

Manajemen isu merupakan hal yang penting dilakukan humas pemerintah. Maraknya hoax media sosial, menjadikan isu jokowi anti islam semakin kuat. Humas pemerintah secara berkala rutin memposting kegiatan Jokowi, salah satunya melalu website setkab.go.id. peneliti berupaya mengetahui framing berita yang dibuat humas untuk meniadakan isu Jokowi antiislam. Berdasarkan daftar kegiatan Presiden Jokowi sejak dilantik Oktober 2014 hingga Juli 2018, terdapat 342 berita yang berfokus pada kegiatan keislaman.

Hadirnya media online seperti website sangat membantu pemerintah memberikan informasi terkait capaian pemerintahan. Dalam perkembangannya, peran media online dalam menyediakan informasi tentu memberikan suatu pengaruh terhadap isi berita yang disampaikan atau yang biasa disebut pembingkaian berita (framing). Ningsih (2013) mengatakan bahwa dalam pemberitaan mengenai penembakan Solikin kedua surat kabar sama-sama menganggap bahwa polisi sebagai penyebab permasalahan. Perbedaan tampak pada surat kabar Jawa Pos lebih menonjolkan sikap polisi dalam menyikapi tuduhan yang menimpa anggota kepolisian. Selain itu Jawa Pos juga menonjolkan isu mengenai tindakan yang dilakukan setelah melakukan penembakan pada Solikin. Persamaan penelitian ini dengan penelitian yang akan dilakukan terletak pada model analisis yang digunakan yaitu analisis framing Robert N. Entman. Adapun perbedaannya terletak pada jenis media yang dianalisis. Penelitian yang dilakukan oleh Nonik Wahyu Ningsih adalah penelitan pada media cetak, sedangkan yang akan peneliti lakukan adalah penelitan pada media online khusus yakni setkab.go.id. Penelitian ini akan berupaya mencari tau framing kegiatan islam yang seringkali ditonjolkan humas untuk menyangkal isu Jokowi Antiislam.

Pembingkaian suatu berita juga dapat dilihat dari penonjolan aspek-aspek tertentu. Ningsih (2013) menyimpulkan bahwa media menggunakan penempatan headline, foto, teks sebagai bentuk penonjolan dan penekanan isu dalam membingkai beritanya, dalam hal ini terkait peristiwa penembakan Solikhin. Menganalisis headline, foto dan teks dalam berita penembakan Solikhin memperlihatkan bahwa pemberitaan media tersebut lebih condong kepada menyalahkan polisi. Penelitian ini nantinya akan berfokus hanya kepada headline dan teks release di website setkab.go.id oleh humas pemerintah.

Keberpihakan suatu media tentu akan mempengaruhi isi suatu berita tetapi tidak hanya dalam hal membela negara, kepemilikan media juga berpengaruh terhadap isi dari berita yang ingin disampaikan. Penelitian Khaerunnisya (2012) menjelaskan bahwa Goal.com memiliki kecenderungan pemberitaan jika kepengurusan PSSI terkait format Liga Indonesia telah melanggar pedoman dan hasil kongres. Penelitian tersebut menggunakan model analisis framing Pan dan Kosicki, sedangkan yang akan peneliti gunakan adalah model analisis framing Robert N. Entman. Paparan di atas dapat memberikan gambaran perbedaan pembingkaian berita yang disajikan oleh kedua media tersebut dipengaruhi oleh kepentingan masing-masing media. peneliti berasumsi karena media setkab.go.id merpakan salah satu media pemerintah, maka framing yang disajikan akan berupaya meningkatkan citra Presiden Jokowi.

Penelitian sebelumnya terkait analisis framing Jokowi pernah dilakukan oleh Flora (2014) yang meneliti tentang analisis framing Jokowi pada tahun 2014-2019 pada surat kabar kaltim post dan tribun kaltim. Perbedaan penelitian terletak pada analisis framing yang digunakan. Flora (2014) menggunakan analisis framing Zhongdang Pan, sementara penelitian ini menggunakan analisis framing Robert Entman. Kemudian hasil penelitian Flora (2014) membuktikan adanya framing khusus pada sosok Dahlan Iskan sebagai pemilik media lokal dan banyak menonjolkan sosok Jokowi. Sementara penelitian ini fokus bukan pada pemberitaan media, namun kebaruan penelitian ini terletak pada framing yang digunakan humas pemerintah untuk menghalau isu melalui release yang diluncurkan di website Setkab.go.id.

Penelitian tentang analisis framing juga pernah dilakukan Damayanti, Mayangsari \& Putra (2016) tentang pemberitaan reklamasi di teluk Jakarta. Penelitian ini ingin mengetahui penonjolan aspek yang ditampilkan oleh majalah Tempo mengenai pemberitaan reklamasi teluk Jakarta pada majalah tempo edisi 23-29 Mei 2016. Hasil penelitian ini 
menunjukan berita pada aspek hukum dan kontribusi tambahan, dimana kontribusi tambahan ini adalah bentuk suap yang dilakukan oleh pengembangan reklamasi, yaitu PT Podomoro Land, dan merupakan barter antara PT. Podomoro Land dengan Gubernur DKI Jakarta, Basuki Tjahaja Purnama. Perbedaan penelitian terletak pada objek yang diambil yakni setkab.go.id yang merupakan media resmi pemerintah, bukan media massa.

Beberapa penelitian sebelumnya hanya berfokus pada framing media massa untuk kajian jurnalistik. Kali ini penelitian memberikan gambaran terkait cara humas menonjolkan frame melalui release. Isi suatu berita atau peristiwa dapat dipengaruhi oleh kepemilikan media, kepentingan politik, dan penonjolan aspek-aspek tertentu yang dianggap dapat menarik perhatian khalayak. Secara umum, peneliti berasumsi bahwa humas pemerintah cenderung memberikan berita positif terkait keislaman Jokowi karena memiliki kepentingan politik yakni humas bertugas membuat dan menjaga reputasi pemerintah. Penelitian ini berupaya melihat pembingkaian berita yang dilakukan sekretariat kabinet sebagai humas pemerintah untuk secara kontinu memperbaiki citra Presiden Jokowi yang dikatakan antiislam.

Kemampuan internet dalam mengintegrasikan berbagai platform, menjadikan teknologi digital memiliki kemampuan untuk mendistribusikan berita dengan gratis, cepat dan interaktif. Media online dalam hal ini portal berita sebagai wadah yang tepat untuk memperluas jaringan pembaca. Teknologi media telah membuat masyarakat sudah sangat bergantung pada teknologi dan tatanan masyarakat terbentuk berdasarkan kemampuan dalam menggunakan teknologi. Pemilihan portal berita setkab.go.id didasari oleh data terlengkap kegiatan harian presiden hanya terpublikasi dari website tersebut. Untuk itu, maka data terkait kegiatan keislaman akan menjadi jauh lebih mudah.

Peneliti menggunakan metode analisis framing Robert N Entman untuk menganalisis konstruksi realitas yang dilakukan oleh release online di setkab.go.id. Metode analisis framing masih jarang digunakan dalam penelitian di bidang kehumasan atau Public Relations (PR). Metode ini memang lebih umum digunakan dalam bidang jurnalistik, yakni menganalisis isi pemberitaan media. Namun, kali ini peneliti secara khusus menggunakan framing dalam kajian kehumasan. Framing menurut Hallahan dalam Kriyantono (2014) menjelaskan bahwa "press release merupakan framing tentang peristiwa atau isu yang dibuat public relations untuk memengaruhi opini publik" (h.316). Artinya, pemerintah mengemas pesan yang mereka sampaikan dengan frame tertentu bertujuan untuk mendefinisikan isu sehingga tercipta citra organisasi yang positif (Kriyantono, 2015). Beberapa hal di atas menjadi landasan peneliti tertarik dan berkeinginan menguji asumsi terkait framing humas pemerintah dalam isu keislaman Jokowi di portal setkab.go.id.

\section{TINJAUAN PUSTAKA}

\section{A. Kajian Framing dalam Kajian Kehumasan}

Analisis framing pada umumnya digunakan dalam penelitian jurnalistik. Dalam konteks humas, framing pada dasarnya merupakan proses memilih beberapa aspek dari realitas dan membuat aspek-aspek terpilih tersebut menjadi lebih menonjol melalui teks yang disampaikan. Analisis framing menurut Wiratama dan Ati (2017) merupakan metode penyajian realitas yakni kebenaran tentang suatu kejadian secara sepihak, sehingga tidak secara penuh melainkan menonjolkan aspek tertentu.

Salah satu peran humas adalah dalam komunikasi krisis. Dalam situasi krisis, sebuah pemerintah perlu melakukan manajemen isu untuk menghindari terjadinya krisis. Organisasi dapat melakukan konstruksi atas realitas guna mendukung kepentingan mereka. Pernyataan resmi pemerintah yang disampaikan melalui berbagai bentuk saluran komunikasi, merupakan upaya untuk melakukan konstruksi atas realitas (Prastya, 2018). Pernyataan resmi memungkinkan untuk mengubah pandangan masyarakat mengenai pemerintah (Kriyantono, 2014). Oleh karena itu, di era digital pemerintah memanfaatkan website resmi mereka untuk mempublikasikan pesan. Artinya, hasil framing pemerintah terhadap sebuah peristiwa, bisa dilihat dari informasi yang ada di website resmi. Keunggulan website resmi adalah organisasi dapat menyampaikan pernyataan secara lengkap, detail, di waktu kapan pun, dan memungkinkan untuk meningkatkan efektivitas komunikasi antara pemerintah dengan media dan public. Itu sebabnya, kehadiran internet menuntut organisasi untuk dapat segera merespon krisis yang terjadi. Pada penelitian ini, Setkab.go.id sebagai website resmi digunakan humas untuk mengonstruksi pesan bahwa Presiden Jokowi banyak menggunakan aktivitas keislaman sehingga menampik isu sebagai sosok antiislam.

Penelitian ini berupaya mencari tau aspek yang memengaruhi pembingkaian berita terkait kegiatan-kegiatan keislaman Jokowi. Isi media memang didasarkan pada kejadian di dunia nyata, namun isi media menampilkan dan menonjolkan elemen tertentu dan logika struktural media dipakai dalam penonjolan elemen tersebut. Bahkan, media tertentu cenderung membatasi dan menyeleksi sumber berita, menafsirkan komentar- komentar sumber berita, dan memberi porsi yang berbeda terhadap perspektif lain. Dengan adanya penonjolan dari beberapa aspek oleh media, maka akan berpengaruh terhadap isi dan pemaknaan terhadap sebuah berita yang disajikan oleh sebua portal berita online. Dalam hal ini, peneliti ingin mencermati aspek penonjolan yang dilakukan oleh portal berita online setkab.go.id dengan menggunakan teknik analisis framing. 


\section{METODE PENELITIAN}

Penelitian ini merupakan jenis penelitian kualitatif. Dalam penelitian kualitatif, teori dianggap bukanlah hal utama melainkan sebuah kisi-kisi sebagai alat untuk menjaring, mengukur, atau bahkan menaklukkan data (Mulyana \& Solatun, 2013). Penelitian kualitatif menurut Prihananto (2014) memayungi sekelompok metodologis yang bertujuan melakukan deskripsi dan interpretasi fenomena sosial. Metode yang termasuk dalam penelitian kualitatif ialah etnografi, etnometodologi, analisis wacana, analisis naratif, grounded teori, fenomenologi, analisis framing, hermeneutika dan analisis percakapan (h.54). Fitur utama penelitian kualitatif menurut Miles, Huberman, dan Saldana (2013) terletak pada fokus kejadian alami. Artinya, peneliti memiliki pegangan kuat pada "kehidupan nyata". Menurut Mulyana \& Solatun (2013) pada tradisi penelitian kualitatif terdapat sejumlah teori atau pendekatan yang menjadi landasan, seperti: fenomenologi, interaksi simbolik, etnometodologi, kajian budaya, feminisme, posmodernisme, dan teori kritis. Analisis framing dipakai untuk membedah cara-cara atau ideologi media saat mengkonstruksi fakta.

Penelitian kali ini menggunakan analisis framing sebagai metode utama. Framing menyediakan dasar untuk humas guna memilih tema-tema yang hendak disampaikan kepada masyarakat dan juga memperkuat pesan kunci pemerintah (Prastya, 2016). Analisis Framing menurut Surbakti (2013) termasuk kedalam pandangan konstruksionis yakni setiap berita yang sampai ke pembaca telah dikonstruksikan oleh pihak tertentu. Pemilihan metode analisis framing dalam penelitian ini karena metode ini merupakan metode yang melihat bagaimana sebuah peristiwa itu dibingkai di pemberitaan release yang dilakukan humas pemerintah.

Model analisis framing yang digunakan dalam penelitian ini adalah model Robert N. Entman. Penelitian ini menggunakan metode framing menurut Robert N. Entman karena konsep ini berbicara mengenai penggambaran proses seleksi dan menonjolkan aspek tertentu dari realitas oleh media. Sehingga dalam seleksi dan penonjolan aspek tersebut akan terlihat pada teks yang dikomunikasikan sedemikian rupa untuk memberikan sebuah gambaran atau sebuah masalah yang lebih khusus melalui keempat elemen yaitu define problem, diagnose cause, make moral judgement, dan treatment recommendation. Empat elemen tersebut digunakan untuk mendapatkan garis besar suatu pemberitaan media. Dengan demikian, analisis model ini akan lebih mudah untuk mengetahui cara humas pemerintah mengemas pemberitaan mengenai kegiatan keislaman Jokowi.

Fokus dalam penelitian ini adalah pemilihan kata-kata dalam pemberitaan tentang kegiatan keislaman Jokowi pada portal berita setkab.go.id. Sumber data yang digunakan dalam penelitian ini merupakan data yang diperoleh dari objek yang diteliti yaitu release setkab.go.id. Data dalam penelitian ini berupa teks berita pada Oktober 2014-Juli 2018. Teknik pengumpulan data pada penelitian ini adalah dokumentasi berupa artikel pemberitaan portal berita setkab.go.id mengenai keislaman Jokowi sejak Oktober 2014 hingga Juli 2018.

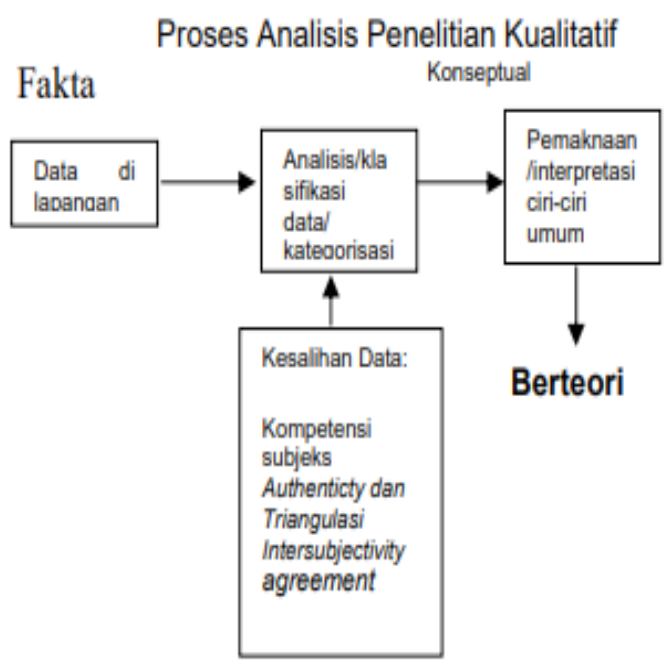

Sumber: (Kriyantono, 2014)

Analisis data kualitatif menurut Kriyantono (2014) dimulai dari mengumpulkan data lapangan. Penelitian ini menggunakan release setkab.go.id sebagai data utama, kemudian data berdasarkan isu yang terkait. Dari keseluruhan berita, peneliti mendapatkan 342 berita keislaman sejak Oktober 2014-Juli 2018. Dari 342 berita keislaman tersebut, peneliti mengambil 2-3 berita yang memiliki view terbanyak di setiap tahunnya. Dari beberapa objek tersebut peneliti mengambil 12 berita yang mewakili keseluruhan kegiatan keislaman Jokowi dari website setkab.go.id. Subjek dari penelitian ini adalah berita-berita kegiatan keislaman Jokowi yang dirilis di website setkab.go.id. Sedangkan objek penelitiannya yaitu frame atau bingkai berita sosok Jokowi terkait kontroversi SARA atau Jokowi Antiislam. Setelah 
melakukan proses klasifikasi, data dipilih kemudian dianatalis menggunakan empat model analisis entman. Robert N. Entman dalam Eriyanto (2009) membagi perangkat analisis framing ke dalam empat elemen yaitu:

1. Define Problems (pendefinisian masalah). Elemen ini merupakan bingkai yang paling utama. Elemen ini menekankan bagaimana peristiwa dipahami ketika ada masalah atau peristiwa, bagaimana peristiwa atau isu tersebut dipahami. Peristiwa yang sama dapat dipahami secara berbeda. Dan bingkai yang berbeda ini akan menyebabkan realitas bentukan yang berbeda.

2. Diagnose Causes (memperkirakan penyebab masalah). Elemen ini merupakan elemen framing untuk membingkai siapa yang dianggap sebagai aktor dari suatu peristiwa. Penyebab disini bisa berarti apa (what), tetapi bisa juga berarti siapa (who).

3. Make Moral Judgement (membuat pilihan moral). Elemen ini merupakan elemen framing yang dipakai untuk membenarkan atau memberikan argumentasi pada pendefinisian masalah yang telah dibuat. Ketika masalah sudah didefinisikan, penyebab masalah sudah ditentukan, dibutuhkan sebuah argumentasi yang kuat untuk mendukung gagasan tersebut.

4. Treatment Recommendation (menekankan penyelesaian). Elemen ini dipakai untuk menilai hal yang dikehendaki oleh humas. Jalan apa yang dipilih untuk menyelesaikan masalah. Penyelesaian itu tentu saja sangat bergantung pada bagaimana peristiwa itu dilihat dan siapa yang dipandang sebagai penyebab masalah.

Robert N. Entman menggambarkan konsep framing sebagai proses seleksi dan penonjolan aspek tertentu suatu realitas oleh media. Entman memberi tekanan lebih pada bagaimana teks ditampilkan dan bagian yang dianggap penting atau ditonjolkan. Dalam prakteknya framing dijalankan oleh media dengan menseleksi isu tertentu serta menonjolkan suatu aspek dari isu tersebut menggunakan berbagai strategi wacana misalnya penempatan pada headline depan, pengulangan, memperkuat penonjolan, dan pemakaian label tertentu dan lain sebagainya.

\section{HASIL DAN ANALISIS}

Berdasarkan rekap data kegiatan keislaman Presiden Joko Widodo sejak dilantik 20 Oktober 2014 hingga 7 Juli 2018 dari situs website setkab.go.id setelah dikalkulasi terdapat 342 keislaman yang telah dilakukan. Dari 342 kegiatan yang dilakukan, peneliti merangkum kegiatan keislaman yang pernah dilakukan dan dipublikasikan tim humas setkab. go.id.

Presiden Jokowi telah membuat berbagai macam kebijakan pada masa pemerintahannya seperti Menandatangani Kepres 24 tahun 2017 terkait Hibah Pemerintah untuk Islamic Center, PP No 57 tahun 2016 tentang UIII, Perpres No.74 tahun 2016 tentang dana pengurus haji, Perpres No. 91 tahun 2016 tentang Komitmen Nasional Keuangan Syariah, Penentuan jam kerja ASN TNI POLRI, PP No.25 tahun 2017 tentang THR, Perrpu 2 tahun 2017 tentang ormas islam, Zikir akbar pertama untuk merayakan dirgahayu NKRI, Penetapan Dien Syamsudin menjadi Utusan Khusus Presiden untuk Dialog Agama dan Perdaban, Peluncuran Bank Wakaf Mikro An-nanawi, Penyelenggaraan Program Beasiswa Santri Berprestasi (PBSP), dan Peringatan Hari Santri sesuai Keppres 22 tahun 2015. Sementara terkait kegiatan keislaman lainnya yakni kebijakan tentang Haji, tercatat Jokowi memiliki 33 kegiatan terkait pelaksanaan haji seperti penurunan dana haji, pembahasan Perpres 64 tahun 2015, pembahasan korban Crane, kepuasan haji, dan pelaksanaan haji.

Presiden Jokowi juga dalam berbagai kesempatan kegiatan keislaman seperti memberikan sambutan, mengundang masyarakat ke istana, melakukan kunjungan ke pondok pesantren tidak lupa untuk selalu memberikan pesan moral. Pesan moral yang selalu diingatkan Presiden Jokowi diantaranya: meminta masyarakat meneladani sifat-sifat nabi Muhammad, mengingatkan toleransi umat beragama, menjauhi rasisme, ajakan melakukan qunut nazillah saat ada musibah, mengingatkan keberagaman, ukhuwah Islamiyah, mengingatkan masyarakat agar tidak meninggalkan sholat, mengajak masyarakat untuk selalu berpikiran positif dan kondusif menjelang tahun politik, mengingatkan agar tidak menyebarkan fitnah dan hoax, dan selalu menyerukan perdamaian.

Presiden Jokowi selalu mengadakan kegiatan keislaman dan merayakan hari-hari besar islam, diantaranya: isra miraj, istighosah Ramadhan, takbir idul adha, nuzulul quran, zakat, buka puasa bersama, sholat iedul fitri, sholat iedul adha, dan maulid nabi. Pada masa kepemimpinannya, Presiden Jokowi turut aktif dalam organisasi keislaman. Beliau mengikuti kegiatan dari berbagai organisasi islam, seperti: OKI, World Islamic Economic Forum (WICF), Islamic American Summit, Forum Komunikasi Umat Beragama, Badan Komunikasi Pemuda Remaja Masjid Indonesia, dan lain sebagainya. Selain itu, Presiden Jokowi juga tercatat melakukan kegiatan ibadah islam, seperti: sholat jumat, takbiran syawal, kunjungan ke berbagai masjid, sholat tarawih, sembako Ramadhan, tahiyatul masjid, sholat gerhana, dan pemberian tanah wakaf. Presiden Jokowi juga telah menjalani kerjasama dengan negara-negara islam, seperti: Arab, Yordania, Oman, Afghanistan, Muslim Tiongkok, dan Pakistan.

Presiden Jokowi juga telah melakukan kunjungan ke berbagai Pondok Pesantren saat berkunjung ke berbagai daerah. Pondok pesantren yang telah dikunjungi Presiden Jokowi yakni Pondok Pesantren (Ponpes) Amanatul Ummah pimpinan Dr. K.H. Asep Saifuddin Chalim, Pondok Modern Darussalam Gontor, Pondok Pesantren Singo Ludiro 
Mojolaban, Pondok Pesantren (Ponpes) Buntet Cirebon, Pondok Pesantren (Ponpes) Cipasung Singaparna, Pondok Pesantren Al Ihya, Pondok Pesantren Darussalam Purwokerto, Pondok Pesantren Al Asy'ariyyah Kalibeber Wonosobo, Pondok Pesantren An-nanawi, Pondok Pesantren Nurul Islam, Pondok Pesantren (Ponpes) Kyai Haji Aqiel Siroj (KHAS) Kempek Cirebon, Pondok Pesantren Salawiyah, Pondok Pesantren (ponpes) Mambaus Sholihin Gresik, Pondok Pesantren As Salafi, Pondok Pesantren Alfal Madiun, Pondok Pesantren Darul Maarif, dan Pondok Pesantren Asshiddiqiyah Karawang.

Terkait Pendidikan keislaman, Presiden Jokowi sangat mendukung Pendidikan keislaman yang diwujudkan dengan pembuktian mendukung transformasi PTKIN, Penandatanganan PP 57 tahun 2017 tentang pendirian UIII, Mendukung Pendidikan karakter, dan menghibahkan 5M bagi pembangunan masjid Ahmad Afghanistan. Peran Presiden Jokowi dalam berbagai konflik keagamaan juga sangat terlibat seperti melakukan pembahasan, pengecaman, hingga penyelesaian kasus terkait konflik agama tolikan, peran dalam kasus WNI Jama Tabligh Fhiliphina, Krisis di Masjidil Aqsa, Pembuatan UU Ormas, Palestina, Hukuman mati, Kasus KPK Polri, ISIS, kasus 7 imigran muslim, dan kasus terorisme.

Dari berbagai kegiatan tersebut, tim humas selalu mencoba menampilkan framing atau pembingkaian berita bahwa Jokowi tidak memiliki rasa anti terhadap islam. Tim humas dalam penyampaian tersebut mencoba melakuka pembingkaian bahwa segala hal yang dilakukan Jokowi sejak dilantik pada Oktober 2014 hingga Juli 2018 membuktikan dedikasinya sebagai pemimpin negara dalam mengembangkan dan menyebarkan syariat islam. Peneliti berupaya menggunakan analisis Entman untuk mengetahui lebih dalam terkait release yang diterbitkan oleh tim humas secretariat kabinet. Berikut 12 berita terpilih yang dilakukan uji analisis:

Tabel 1. Berita dengan View Terbanyak

\begin{tabular}{|c|c|c|c|c|}
\hline No & Judul Berita & Tanggal & View & Link \\
\hline 1 & $\begin{array}{l}\text { Presiden Jokowi: Hanya di } \\
\text { Indonesia, Islam dan Demokrasi } \\
\text { Berjalan Beriringan }\end{array}$ & $\begin{array}{l}19 \text { Desember } \\
2014\end{array}$ & 23360 & $\begin{array}{l}\text { https://setkab.go.id/presiden-jokowi- } \\
\text { hanya-di-indonesia-is lam-dan- } \\
\text { demokrasi-berjalan-beriringan/ }\end{array}$ \\
\hline 2 & $\begin{array}{l}\text { Kunjungi Pesantren, Presiden } \\
\text { Jokowi: Timur Tengah Berharap } \\
\text { Indonesia Jadi Motor Perdamaian }\end{array}$ & 17 April 2015 & 45565 Views & $\begin{array}{l}\text { http://setkab.go.id/kunjungi- } \\
\text { pesantren-presiden-jokowi-timur- } \\
\text { tengah-berharap-indonesia-jadi- } \\
\text { motor-perdamaian/ }\end{array}$ \\
\hline 3 & $\begin{array}{l}\text { Presiden Jokowi Ajak Raja } \\
\text { Yordania Kerjasama Suarakan } \\
\text { Persatuan Umat Islam Dunia } \\
\end{array}$ & 23 April 2015 & 40717 views & $\begin{array}{l}\text { https://setkab.go.id/presiden-jokowi- } \\
\text { aj ak-raja-y ordania-kerja s a ma- } \\
\text { suarakan-persatuan-umat-islam-dunia/ }\end{array}$ \\
\hline 4 & $\begin{array}{l}3 \text { WNI Jadi Korban Tewas, } \\
\text { Presiden Jokowi Sampaikan Duka } \\
\text { Cita Peristiwa Mina }\end{array}$ & $\begin{array}{l}24 \quad \text { September } \\
2015\end{array}$ & 39697 Views & $\begin{array}{l}\text { https://setkab.go.id/3-wni-jadi- } \\
\text { korban-tewas-presiden-jokowi- } \\
\text { sampaikan-duka-cita-korban-tragedi- } \\
\text { mina/ }\end{array}$ \\
\hline 5 & $\begin{array}{l}\text { Buka KTT LB OKI, Presiden } \\
\text { Jokowi: OKI Harus jadi Bagian } \\
\text { Dari Solusi Palestina }\end{array}$ & 7 Maret 2016 & 13458 Views & $\begin{array}{l}\text { http://setkab.go.id/buka-ktt-lb-oki- } \\
\text { presiden-jokowi-oki-harus-jadi- } \\
\text { bagian-dari-solusi-palestina/ }\end{array}$ \\
\hline 6 & $\begin{array}{l}\text { Presiden Jokowi Ajak Menteri } \\
\text { dan Pejabat Eselon I Tunaikan } \\
\text { Zakat Lewat Baznas }\end{array}$ & 30 Juni 2016 & 39811views & $\begin{array}{l}\text { https://setkab.go.id/presiden-jokowi- } \\
\text { ajak-menteri-dan-pejabat-eselon-i- } \\
\text { tunaikan-zakat-lewat-baznas/ }\end{array}$ \\
\hline 7 & $\begin{array}{l}\text { Perintah Presiden Harus Selesai } \\
2 \text { Pekan, Gelar Perkara Kasus } \\
\text { Dugaan Penistaan Agama } \\
\text { Dilakukan Terbuka }\end{array}$ & $\begin{array}{l}6 \quad \text { November } \\
2016\end{array}$ & 31056 Views & $\begin{array}{l}\text { http://setkab.go.id/perintah-presiden- } \\
\text { harus-selesai-2-pekan-gelar-perkara- } \\
\text { kasus-dugaan-penistaan-agama- } \\
\text { dilakukan-terbuka/ }\end{array}$ \\
\hline 8 & $\begin{array}{l}\text { Bertemu Tokoh Lintas Agama, } \\
\text { Raja Salman Apresiasi Kerukunan } \\
\text { Beragama di Indonesia }\end{array}$ & 3 Maret 2017 & 58785 Views & $\begin{array}{l}\text { https://setkab.go.id/bertemu-tokoh- } \\
\text { lintas-agama-raja-salman-apresiasi- } \\
\text { kerukunan-beragama-di-indonesia/ }\end{array}$ \\
\hline 9 & $\begin{array}{l}5 \text { MoU Diteken, Pembangunan } \\
\text { Masjid As Salam di Indonesia } \\
\text { Islamic Center Kabul Telah } \\
\text { Selesai }\end{array}$ & 5 April 2017 & 33220 Views & $\begin{array}{l}\text { http://setkab.go.id/5-mou-diteken- } \\
\text { pembangunan-masjid-as-salam-di- } \\
\text { indonesia-islamic-center-kabul-telah- } \\
\text { selesai/ }\end{array}$ \\
\hline
\end{tabular}




\begin{tabular}{|c|c|c|c|c|}
\hline 10 & $\begin{array}{l}\text { Presiden Jokowi: Umat Sudah } \\
\text { Tunjukkan Pada Dunia, Islam } \\
\text { Adalah Agama Yang Cinta Damai }\end{array}$ & 4 Mei 2017 & 17827 Views & $\begin{array}{l}\text { http://setkab.go.id/presiden-jokowi- } \\
\text { umat-sudah-tunjukkan-pada-dunia- } \\
\text { islam-adalah-agama-yang-cinta- } \\
\text { damai/ }\end{array}$ \\
\hline 11 & $\begin{array}{l}\text { Buka Puasa di Cilangkap, } \\
\text { Presiden Jokowi: TNI dan Rakyat } \\
\text { Seperti Air dan Ikan, Tak Bisa } \\
\text { Dipisahkan }\end{array}$ & 19 Juni 2017 & 20134 Views & $\begin{array}{l}\text { http://setkab.go.id/buka-puasa-di- } \\
\text { cilangkap-presiden-jokowi-tni-dan- } \\
\text { rakyat-seperti-air-dan-ikan-tak-bisa- } \\
\text { dipisahkan/ }\end{array}$ \\
\hline 12 & $\begin{array}{l}\text { Terima Syekh Al-Azhar, Presiden } \\
\text { Jokowi Bahas Kerja Sama } \\
\text { Syiarkan 'Wasathiyah Islam' }\end{array}$ & 30 April 2018 & 20888 Views & $\begin{array}{l}\text { https://setkab.go.id/terima-syekh-al- } \\
\text { azhar-presiden-jokowi-bahas-kerja- } \\
\text { sama-syiarkan-wasathiyah-islam/ }\end{array}$ \\
\hline
\end{tabular}

Tabel 2. Analisis Release Setkab.go.id Menggunakan Analisis Entman

\begin{tabular}{|c|c|c|}
\hline Tanggal & Elemen & Interpretasi \\
\hline \multirow[t]{4}{*}{$\begin{array}{l}19 \text { Desember } \\
2014\end{array}$} & Define Problem (definisi masalah) & $\begin{array}{l}\text { Presiden Joko Widodo (Jokowi) meresmikan } \\
\text { Transformasi Perguruan Tinggi Keagamaan Islam } \\
\text { Negeri (PTKIN) dan Peluncuran Program 5.000 } \\
\text { Doktor Tahun 2015-2019 }\end{array}$ \\
\hline & Diagnose Cause (penyebab masalah) & $\begin{array}{l}\text { Terorisme dan Indonesia negara islam. Keputusan } \\
\text { memberikan rumah sakit dan kementerian agama } \\
\text { pada uin }\end{array}$ \\
\hline & Make moral judgement (keputusan moral) & $\begin{array}{l}\text { Pendidikan islam penting dibuat untuk membangun } \\
\text { peradaban islam }\end{array}$ \\
\hline & Suggest remidies (penyelesaian) & $\begin{array}{l}\text { Setkab.go.id menampilkan Jokowi sangat } \\
\text { mengharapkan Indonesia menjadi kiblat pendidikan } \\
\text { islam dunia }\end{array}$ \\
\hline \multirow[t]{4}{*}{17 April 2015} & Define Problem (definisi masalah) & $\begin{array}{l}\text { Presiden Jokowi menjalin silaturahmi berdialog } \\
\text { dengan masyarakat dan tokoh agama yang diundang } \\
\text { oleh pimpinan Ponpes Amanatul Ummah. }\end{array}$ \\
\hline & Diagnose Cause (penyebab masalah) & $\begin{array}{l}\text { Ponpes Amanatul Ummah telah banyak melahirkan } \\
\text { ulama, pemimpin, pengusaha, profesional yang } \\
\text { memberi kebaikan kepada bangsa }\end{array}$ \\
\hline & Make moral judgement (keputusan moral) & $\begin{array}{l}\text { Negara-negara Timur Tengah berharap Indonesia } \\
\text { menjadi motor perdamaian bagi negara-negara } \\
\text { tersebut seperti kasus Yaman terakhir. Indonesia } \\
\text { diharapkan menjadi negara mediator }\end{array}$ \\
\hline & Suggest remidies (penyelesaian) & $\begin{array}{l}\text { Berita ini memberikan efek positif dan meyakinkan } \\
\text { masyarakat bahwa presiden Jokowi merupakan } \\
\text { sosok islami yang disegani pihak luar }\end{array}$ \\
\hline \multirow[t]{4}{*}{23 April 2015} & Define Problem (definisi masalah) & $\begin{array}{l}\text { Presiden Jokowi mengajak Raja Abdullah agar } \\
\text { Pemerintah Yordania bisa bekerja sama dengan } \\
\text { Indonesia untuk menyuarakan persatuan umat } \\
\text { Islam di dunia. }\end{array}$ \\
\hline & Diagnose Cause (penyebab masalah) & $\begin{array}{l}\text { Umat islam harus bersatu, jika tidak akan mudah } \\
\text { dilemahkan. }\end{array}$ \\
\hline & Make moral judgement (keputusan moral) & $\begin{array}{l}\text { Jika kekuatan islam disatukan maka akan } \\
\text { memberikan banyak dampak positif }\end{array}$ \\
\hline & Suggest remidies (penyelesaian) & $\begin{array}{l}\text { Terjadi penawaran terkait hubungan business to } \\
\text { business, penanaman saham, penguatan kerjasama, } \\
\text { dan permintaan bantuan untuk menjadikan } \\
\text { Indonesia anggota DK PBB }\end{array}$ \\
\hline
\end{tabular}




\begin{tabular}{|c|c|c|}
\hline \multirow[t]{4}{*}{$\begin{array}{l}24 \text { September } \\
2015\end{array}$} & Define Problem (definisi masalah) & $\begin{array}{l}\text { Jokowi sampaikan duka cita mendaam atas korban } \\
\text { mina, termasuk } 3 \text { warga negara Indonesia }\end{array}$ \\
\hline & Diagnose Cause (penyebab masalah) & $\begin{array}{l}\text { Peristiwa mina menewaskan } 3 \text { WNI, warga negara } \\
\text { Mesir, dan Amerika }\end{array}$ \\
\hline & Make moral judgement (keputusan moral) & $\begin{array}{l}\text { Presiden Jokowi ditampilkan peduli pada kejadian } \\
\text { bencana di negara Islam }\end{array}$ \\
\hline & Suggest remidies (penyelesaian) & $\begin{array}{l}\text { Framing dari release menampakkan negara } \\
\text { berduka dari statement twitter Jokowi }\end{array}$ \\
\hline \multirow[t]{4}{*}{7 Maret 2016} & Define Problem (definisi masalah) & $\begin{array}{l}\text { Presiden Joko Widodo secara resmi membuka } \\
\text { Konferensi Tingkat Tinggi Luar Biasa Organisasi } \\
\text { Kerja Sama Islam (KTT LB OKI) ke-5 di Jakarta } \\
\text { Senayan, Senin (7/3). Menjadi sebuah penghargaan } \\
\text { Indonesia bisa menjadi tuan rumah OKI }\end{array}$ \\
\hline & Diagnose Cause (penyebab masalah) & $\begin{array}{l}\text { Presiden Jokowi menyampaikan bahwa } \\
\text { perkembangan situasi politik dan keamanan } \\
\text { global dewasa ini tidak boleh menggeser perhatian } \\
\text { masyarakat internasional pada persoalan Palestina. }\end{array}$ \\
\hline & Make moral judgement (keputusan moral) & $\begin{array}{l}\text { Diselenggarakannya OKI di Indonesia merupakan } \\
\text { sebuah prestasi bahwa Indonesia diakui }\end{array}$ \\
\hline & Suggest remidies (penyelesaian) & $\begin{array}{l}\text { Pertemuan Jokowi dan tokoh negara di OKI } \\
\text { menjadi sinyal persatuan dukungan kepada } \\
\text { palestina. Indonesia mencari dukungan PBB untuk } \\
\text { membantu palestina }\end{array}$ \\
\hline \multirow[t]{4}{*}{30 Juni 2016} & Define Problem (definisi masalah) & $\begin{array}{l}\text { Presiden Joko Widodo (Jokowi) mengajak menteri } \\
\text { Kabinet Kerja dan pejabat eselon } 1 \text { di sejumlah } \\
\text { kementerian dan lembaga }(\mathrm{K} / \mathrm{L}) \text { untuk bersama- } \\
\text { sama menunaikan zakat melalui Badan Amil Zakat } \\
\text { Nasional (BAZNAS) di Istana Negara }\end{array}$ \\
\hline & Diagnose Cause (penyebab masalah) & Zakat merupakan ibadah umat islam. \\
\hline & Make moral judgement (keputusan moral) & $\begin{array}{l}\text { Ketua baznas Bambang mengungkapkan inisitif } \\
\text { zakat bersama dapat dijadikan tradisi tahunan }\end{array}$ \\
\hline & Suggest remidies (penyelesaian) & $\begin{array}{l}\text { Jokowi dibingkai sebagai tokoh yang memberikan } \\
\text { inisiasi terhadap pemberian zakat secara bersama } \\
\text { oleh pemerintah }\end{array}$ \\
\hline \multirow[t]{4}{*}{$\begin{array}{l}6 \text { November } \\
2016\end{array}$} & Define Problem (definisi masalah) & $\begin{array}{l}\text { Presiden Jokowi meminta kasus penistaan Ahok } \\
\text { dibuka }\end{array}$ \\
\hline & Diagnose Cause (penyebab masalah) & $\begin{array}{l}\text { Proses persidangan jika tidak dilakukan secara } \\
\text { transparansi maka akan menimbulkan banyak } \\
\text { pertanyaan khalayak }\end{array}$ \\
\hline & Make moral judgement (keputusan moral) & $\begin{array}{l}\text { Pemerintah berupaya mengawal proses hokum } \\
\text { Ahok secara tegas, cepat dan transparan }\end{array}$ \\
\hline & Suggest remidies (penyelesaian) & $\begin{array}{l}\text { Presiden Jokowi ditampilkan jujur dan tidak } \\
\text { memihak dalam kasus Ahok dan menjunjung tinggi } \\
\text { nilai transparansi }\end{array}$ \\
\hline
\end{tabular}




\begin{tabular}{|c|c|c|}
\hline \multirow[t]{4}{*}{3 Maret 2017} & Define Problem (definisi masalah) & $\begin{array}{l}\text { Raja Arab Saudi, Salman bin Abdul Aziz Al-Saud, } \\
\text { mengapresiasi kerukunan antar umat beragama di } \\
\text { Indonesia. Raja berharap agar setiap warga negara } \\
\text { dapat memegang teguh nilai-nilai toleransi di } \\
\text { masyarakat. }\end{array}$ \\
\hline & Diagnose Cause (penyebab masalah) & $\begin{array}{l}\text { Presiden Jokowi sebagai kepala negara ditampilkan } \\
\text { sebagai sosok yang menyatukan berbagai tokoh } \\
\text { agama. Beberapa negara dunia lain sulit menjaga } \\
\text { toleransi antarumat beragama }\end{array}$ \\
\hline & Make moral judgement (keputusan moral) & $\begin{array}{l}\text { Pemerintah berupaya menjaga kerukunan umat } \\
\text { beragama }\end{array}$ \\
\hline & Suggest remidies (penyelesaian) & $\begin{array}{l}\text { Setkab.go.id memperlihatkan keseriusan Jokowi } \\
\text { dalam menjaga toleransi antarumat agama }\end{array}$ \\
\hline \multirow[t]{4}{*}{5 April 2017} & Define Problem (definisi masalah) & $\begin{array}{l}\text { Presiden Joko Widodo (Jokowi) mengemukakan, } \\
\text { pertemuannya dengan Presiden Republik Islam } \\
\text { Afghanistan Mohammad Ashraf Ghani yang } \\
\text { dilanjutkan dengan pertemuan bilateral kedua } \\
\text { negara membahas beberapa isu, di antaranya kerja } \\
\text { sama pembangunan perdamaian. }\end{array}$ \\
\hline & Diagnose Cause (penyebab masalah) & $\begin{array}{l}\text { Indonesia telah membangun Indonesia Islamic } \\
\text { Center di Kabul, ibukota Afghanistan. Indonesia } \\
\text { Islamic Center ini memiliki visi untuk mendorong } \\
\text { penyebaran Islam yang rahmatan lil alamin. Kali } \\
\text { ini, gentian Afghanistan yang berkunjung ke } \\
\text { Indonesia. }\end{array}$ \\
\hline & Make moral judgement (keputusan moral) & $\begin{array}{l}\text { Presiden Jokowi menandatangani } 5 \text { mou kerjasama } \\
\text { dengan afganistan dan persetujuan membangun } \\
\text { perdamaian }\end{array}$ \\
\hline & Suggest remidies (penyelesaian) & $\begin{array}{l}\text { Setkab.go.id ingin menampilkan Presiden Jokowi } \\
\text { memiliki hubungan baik dengan negara-negara } \\
\text { konflik }\end{array}$ \\
\hline \multirow[t]{4}{*}{4 Mei 2017} & Define Problem (definisi masalah) & $\begin{array}{l}\text { Presiden Joko Widodo (Jokowi) memberikan } \\
\text { sambutan kepada musbaqah lil alamin dengan } \\
\text { mengatakan bahwa umat Islam sudah dan terus } \\
\text { menunjukkan pada dunia bahwa Islam adalah } \\
\text { agama yang cinta damai, menjauhi fitnah, menjauhi } \\
\text { kekerasan, agama yang Rahmatan Lil Alamin. }\end{array}$ \\
\hline & Diagnose Cause (penyebab masalah) & $\begin{array}{l}\text { Perlombanaan musabaqah menjadi salah satu } \\
\text { kompetisi yang diperhitungkan dalam dunia islam }\end{array}$ \\
\hline & Make moral judgement (keputusan moral) & $\begin{array}{l}\text { Pemerintah mempersiapkan Musabaqah tingkat } \\
\text { Asia Pasifik dan Musabaqah Hafalan Alquran dan } \\
\text { Hadis Pangeran Sultan bin Abdul Aziz Alu Su'ud } \\
\text { tingkat nasional dengan sebaik-baiknya }\end{array}$ \\
\hline & Suggest remidies (penyelesaian) & $\begin{array}{l}\text { Setkab.go.id ingin menampilkan bahwa Jokowi } \\
\text { sangat peduli dan memberikan bdukungan penuh } \\
\text { kepada hafiz atau hafizah yang berprestasi }\end{array}$ \\
\hline
\end{tabular}




\begin{tabular}{|c|c|c|}
\hline \multirow[t]{4}{*}{19 Juni 2017} & Define Problem (definisi masalah) & $\begin{array}{l}\text { Presiden Jokowi mengingatkan tugas besar TNI } \\
\text { saat buka puasa bersama untuk menjaga keamanan } \\
\text { negara. Penyebaran terorisme dan kesalahan } \\
\text { ideologi negara harus dihentikan }\end{array}$ \\
\hline & Diagnose Cause (penyebab masalah) & $\begin{array}{l}\text { Menjelang hari raya idul fitri marak tindak } \\
\text { kejahatan, keamanan dari TNI harus ditingkatkan }\end{array}$ \\
\hline & Make moral judgement (keputusan moral) & $\begin{array}{l}\text { Pemerintah terus memperkuat mental bela negara } \\
\text { dan kesatuan bangsa }\end{array}$ \\
\hline & Suggest remidies (penyelesaian) & $\begin{array}{l}\text { Setkab.go.id berupaya menampilkan komitmen } \\
\text { presiden dan TNI dalam menjaga kedaulatan } \\
\text { bangsa dan keamanan dari terorisme dan perusakan } \\
\text { ideologi negara }\end{array}$ \\
\hline \multirow[t]{4}{*}{30 April 2018} & Define Problem (definisi masalah) & $\begin{array}{l}\text { Presiden Jokowi melakukan pertemuan High } \\
\text { Level Consultation mengenai masalah Wasathiyah } \\
\text { Islam bersama Grand Syekh Al Azhar Ahmad } \\
\text { Muhammad Ath-thayeb }\end{array}$ \\
\hline & Diagnose Cause (penyebab masalah) & Perlunya wawasan tengah keislaman \\
\hline & Make moral judgement (keputusan moral) & $\begin{array}{l}\text { Pemerintah berupaya menjadikan wawasan tengah } \\
\text { keislaman agar aliran tidak terjerumus pada } \\
\text { radikalisme }\end{array}$ \\
\hline & Suggest remidies (penyelesaian) & $\begin{array}{l}\text { Presiden Jokowi ditampilkan sebagai sosok yang } \\
\text { sangat mencintai ajaran islam seperti watasiyah } \\
\text { islamiyah }\end{array}$ \\
\hline
\end{tabular}

Robert N. Entman menekankan bahwa konsep framing berfokus pada pemberian definisi, penjelasan, evaluasi, dan rekomendasi dalam suatu wacana untuk menekankan kerangka berpikir tertentu terhadap peristiwa yang sedang diwacanakan. Dari hasil temuan data di atas, peneliti menganalisis setiap berita sesuai elemen framing Robert N. Entman dan hasilnya sebagai berikut:

Robert N. Entman menekankan bahwa konsep framingnya berbicara mengenai pemberian definisi, penjelasan, evaluasi, dan rekomendasi dalam suatu wacana untuk menekankan kerangka berpikir tertentu terhadap peristiwa yang sedang diwacanakan (Eriyanto, 2009, p. 187-188). Dari hasil temuan data di atas, peneliti menganalisis setiap berita sesuai elemen framing Robert N. Entman.

Fakta yang ditonjolkan oleh tulisan humas pemerintah di setkab.go.id bahwa Jokowi tampak tenang dan tetap menjalankan kegiatan keislaman meskipun diisukan antiislam. Jokowi ditonjolkan tidak terpengaruh dalam perkataan, "Islam dan demokrasi bisa berjalan beriringan, dan saya meyakini menjadi modal besar kita juga kekuatan kita dalam rangka politik global," tutur Jokowi. Dalam berita tersebut, setkab.go.id menggunakan kalimat langsung dalam penulisan beritanya.

Presiden Jokowi juga bercerita saat meresmikan Transformasi Perguruan Tinggi Keagamaan Islam Negeri (PTKIN) dan Peluncuran Program 5.000 Doktor Tahun 2015-2019, di Istana Negara, Jakarta, Jumat (19/12) siang bahwa dalam setiap pertemuan dengan pemimpin dunia, juga dengan tamu negara, dirinya selalu sampaikan bahwa Indonesia adalah Negara Islam yang terbesar di dunia, dan juga sekaligus negara demokrasi yang terbesar juga di dunia. Hal ini jika dikaitkan dengan argument Rich (2010) yakni release berita setkab.go.id sudah menerapkan beberapa poin menulis yang baik, yakni menggunakan Bahasa yang umum, langsung pada poin penting, dan informasi penting diletakkan di dua paragraph pertama. Pada release tersebut, Jokowi tampak jelas menampilkan informasi terkait transformasi perguruan tinggi islam dan diperjelas di awal paragraf.

Humas melalui releasenya sangat berupaya untuk menampikan sosok Jokowi sebagai pribadi yang pro islam. Dengan memasukkan kutipan langsung pernyataan Jokowi, maka setkab.go.id berusaha untuk menunjukkan emosi atau perasaan yang dirasakan Jokowi yakni islam sebagai sebuah kekuatan dan modal besar dari politik global. Ungkapan itu juga memberikan arti bahwa tuduhan antiislam disangkal secara tidak langsung, hal ini jelas tampak dari cara Jokowi yang tegas mengungkap dukungannya dan simpatinya terhadap islam. Framing yang dibentuk terus terang mengatakan bahwa Jokowi adalah pemimpin negara yang taat islam, tidak seperti isu yang beredar di masyarakat.

Pada teks berita 17 April 2015, setkab.go.id menggambarkan pribadi Jokowi melalui kalimat pasif, yakni: "Presiden mengingatkan, peran ulama mengajarkan kepada masyarakat tentang Islam yang moderat dan Rahmatan Lil Alamin disampaikan dengan baik. Dengan demikian, pemerintah akan berperan untuk terus menjaga negara tenteram dan menjadi contoh bagi negara yang lain”. Ungkapan ini memberikan framing positif kepada presiden yang kemudian 
ditambahkan kegiatan sholat maghrib berjamaah. Dengan pemberitaan semacam ini, Jokowi dibingkai sebagai pribadi yang dekat dengan ulama dan mengajak ulama untuk menjadi agen persatuan dan kedamaian.

Selanjutnya, pada berita periode April 2015, Jokowi ditonjolkan melakukan peningkatan kerjasama dengan Raja Yordania Abdullah. Bahkan penonjolan yang dilakukan setkab.go.id diperkuat dengan penulisan dua kali perihal Jokowi yang akan mengembangkan bisnis ke negara-negara islam. Kebijakan dan aktivitas yang dilakukan benar-benar menguatkan bahwa misi utamanya ialah membangun peradaban islam dari sektor ekonomi dan bisnis. Menurut Danesi (2010) penggunaan judul berita dengan menuliskan sosok Jokowi saja, merupakan sebuah sinekdoke yaitu, "teknik dimana suatu bagian mewakili keseluruhan, keseluruhan mewakili sebagian, spesies mewakili genus," (Danesi, 2010). Pembingkaian terhadap sebuah topik, baik individual, kelompok, dan organisasi dapat menentukan peran pentingnya tokoh tersebut. Ketika sebuah judul yang tidak terlalu dikenal publik yang telah dibingkai, maka interpretasinya akan diatur oleh frame tersebut". Berkaitan dengan hal itu, Jokowi sangat berperan sebagai tokoh protagonist dengan menawarkan kerjasama secara terbuka.

Tidak berhenti pada kegiatan hariannya, pada release humas di setkab.go.id Presiden Jokowi ditampilkan melalui akun twitternya menyampaikan dukacita. "Dukacita mendalam atas peristiwa Mina. Harus ada perbaikan pengelolaan haji supaya peristiwa ini tidak terulang lagi," tulis Presiden Jokowi melalui akun twitternya @jokowi, yang diunggahnya Kamis (23/9) malam. Tulisan di media social memberikan dampak kepada seluruh masyarakat bahwa Jokowi menyampaikan pesan personal terkait duka cita. Penggunaan@jokowi juga menjadi pertimbangan penting, bahwa diri Jokowi benarbenar turut berduka cita.

Dalam releasenya, Presiden Jokowi pun sempat menyampaikan bahwa Dunia Islam kembali menyerukan agar proses perdamaian jangan ditunda-tunda lagi untuk mewujudkan kemerdekaan Palestina melalui "Solusi Dua Negara" (TwoState Solution),". Hal ini memberikan isyarat bahwa Presiden Jokowi ditampilkan sangat peduli terhadap isu kemanusiaan rakyat palestina dan mengajak negara lain atas nama islam untuk berjuang bersama mewujudkan kemerdekaan Palestina.

Hal ini didukung ungkapan Ketua Baznas Bambang secara langsung mengatakan "Semoga apa yang Bapak teladankan itu menjadi tradisi baru yang baik dan berkelanjutan, dan kemudian terus berkembang dan ditiru oleh semua kepala daerah di Indonesia,". Ungkapan tersebut mengartikan bahwa Jokowi ditampilkan sebagai sosok yang menginisiasi adanya pemberian zakat secara bersama.

Meskipun seringkali diisukan sebagai Presiden antiislam, humas sekretariat kabinet seringkali menyisipkan ungkapan tokoh lain. Misalnya Presiden Jokowi justru mendapatkan pujian dari Raja Arab Saudi, Salman bin Abdul Aziz Al-Saud. Ia mengapresiasi kerukunan antar umat beragama di Indonesia. Raja berharap agar setiap warga negara dapat memegang teguh nilai-nilai toleransi di masyarakat. Raja Salman yang didampingi Presiden Joko Widodo (Jokowi) saat berdialog dengan tokoh lintas agama, di Hotel Raffles, Kuningan, Jakarta Selatan, Jumat (3/3) sore. Raja berjuluk Pelayan Dua Tempat Suci itu juga mendorong seluruh pihak untuk aktif menjaga perdamaian, dan sangat penting menanggulangi segala bentuk radikalisme dan ekstremisme yang saat ini makin menggejala.

Presiden Jokowi dalam konferensi pers bersama Presiden Afghanistan Mohammad Ashraf Ghani, di Istana Merdeka, Jakarta, Rabu (5/4) sore. Framing berita menyampaikan pencapaian Indonesia telah membangun Indonesia Islamic Center di Kabul, ibukota Afghanistan. Indonesia Islamic Center ini memiliki visi untuk mendorong penyebaran Islam yang rahmatan lil alamin. "Indonesia Islamic Center di kabul menyediakan sarana ibadah kesehatan dan pendidikan yang akan bermanfaat bagi masyarakat Afghanistan," ujar Presiden. Presiden Jokowi ditampilkan sangat matang dalam mengajak dalam kebaikan dan perdamaian melalui berbagai upaya kerjasama dengan negara-negara islam.

Presiden Jokowi dalam pembukaan Musabaqah Asia Pasifik 4 Mei 2017 berkata, "Teruslah berlatih, memacu diri untuk berprestasi di kesempatan-kesempatan yang akan datang. Dan yang paling penting di semua adalah teruslah mensyiarkan, teruslah mengamalkan ajaran Alquran di luar kompetisi ini,”. Kalimat tersebut mengartikan dukungan penuh terhadap syiar dan pengalaman agama islam.

Selain itu dalam berita-berita di sektkab.go.id, selain menampilkan kegiatan, peneliti melihat adanya sindiran yang diberikan oleh pemerintah kepada pembenci Jokowi. Hal ini memperkuat sosok Jokowi sebagai media darling di media online karena apapun yan dilakukan oleh media darling, baik ia melakukan kesalahan, namun media akan berusaha mengolah pemberitaan hingga publik dapat bersikap menerima dan mau memaklumi kesalahan yang dilakukan media darling tersebut. Media darling artinya, Jokowi merupakan sosok yang seringkali mendapat perhatian dari media. Keseluruhan hal ini tidak terlepas dari peran humas pemerintah yakni sekretariat kabinet dan Kantor Staf Presiden dalam melakukan framing untuk membersihkan isu tersebut dari opini publik.

Ada beberapa faktor yang mempengaruhi penonjolan ini, yang pertama adalah nilai berita prominence yakni nilai berita diukur dari kebesaran peristiwanya atau pentingnya. Peristiwa yang diberitakan adalah peristiwa yang dianggap penting (Eriyanto, 2009, p. 106). Sosok Jokowi merupakan tokoh yang dianggap penting karena ketika berita dinaikkan (diupload ke web). Popularitas Jokowi menjadi nilai berita yang menjual dan dimanfaatkan untuk meningkatkan jumlah hit atau page views mereka. Nilai berita yang kedua adalah conflict atau controversy yakni peristiwa yang mengandung konflik lebih potensial disebut berita dibandingkan dengan peristiwa biasa-biasa saja (Eriyanto, 2009, p. 106). Dalam 
pemberitaan ini, isu SARA, atau lebih tepatnya isu Jokowi antiislam telah menjadi hal yang sensitif di Indonesia.

Dari pemberitaan di setkab.go.id Jokowi dibingkai oleh humas pemerintah dalam hal ini sekretariat negara sebagai pemimpin politik yang taat beragama islam. Walaupun ia menjadi korban dalam kasus isu SARA, namun Jokowi tetap mau menunjukkan kinerjanya untuk kerja dan menjalin hubungan baik melalui aktivitas-aktivitas keislamannya. Dengan pemberitaan positif pada Jokowi melalui release hariannya, maka Jokowi akan mudah untuk dicalonkan kembali. Pembingkaian yang dilakukan oleh setkab.go.id merupakan salah satu upaya untuk membentuk suatu pemikiran menjadi wajar di benak pembaca. Tujuan setkab.go.id adalah agar Jokowi yang merupakan calon wakil presiden kembali terpilih.

Selain itu, pada masa kepemimpinannya, Presiden Jokowi turut aktif dalam organisasi keislaman seperti: OKI, World Islamic Economic Forum (WICF), Islamic American Summit, Forum Komunikasi Umat Beragama, Badan Komunikasi Pemuda Remaja Masjid Indonesia, dan lain sebagainya. Terkait kebijakan tentang Haji, tercatat Jokowi memiliki 33 kegiatan terkait pelaksanaan haji seperti penurunan dana haji, pembahasan Perpres 64 tahun 2015, pembahasan korban Crane, kepuasan haji, dan pelaksanaan haji.

Serta Presiden Jokowi ditampilkan seringkali menanamkan nilai nilai moral keislaman dan meminta masyarakat untuk meneladani sifat-sifat nabi Muhammad, mengingatkan toleransi umat beragama, menjauhi rasisme, ajakan melakukan qunut nazillah saat ada musibah, mengingatkan keberagaman, ukhuwah Islamiyah, mengingatkan agar tidak menyebarkan fitnah dan hoax, dan selalu menyerukan perdamaian.

Presiden Jokowi juga telah menjalani kerjasama dengan negara-negara islam, seperti: Arab, Yordania, Oman, Afghanistan, Muslim Tiongkok, dan Pakistan. Peran Presiden Jokowi dalam berbagai konflik keagamaan juga sangat terlibat seperti melakukan pembahasan, pengecaman, hingga penyelesaian kasus terkait konflik agama tolikan, peran dalam kasus WNI Jama Tabligh Fhiliphina, Krisis di Masjidil Aqsa, Pembuatan UU Ormas, Palestina, Hukuman mati, Kasus KPK Polri, ISIS, kasus 7 imigran muslim, dan kasus terorisme. Keseluruhan hal terkait kegiatan keislaman Jokowi menjadi framing positif yang ditanamkan humas pemerintah untuk membentuk opini publik.

\section{KESIMPULAN}

Berdasarkan hasil analisis framing yang telah dilakukan terhadap portal berita Setkab.go.id pada periode Oktober 2014 hingga Juli 2018 dapat disimpulkan bahwa ditemukan 342 artikel berita setkab.go.id yang menampilkan bingkai positif terhadap kegiatan keislaman Presiden Jokowi. Penelitian ini membuktikan bahwa analisis framing dapat digunakan dalam kajian kehumasan. Setiap release yang dikeluarkan humas Setkab.go.id cenderung berupaya menampilkan kinerja pemerintah dalam menghalau isu negatif tentang Jokowi yang antiislam. Melalui isi artikel seperti pemilihan judul, pemilihan sumber berita, dan pemilihan kutipan yang mendukung suatu pernyataan bahwa Presiden Jokowi memiliki perhatian tinggi terhadap penyebaran dan perkembangan peradaban islam. Peneliti menemukan tiga topik besar yang dibahas dalam pemberitaan tersebut yaitu tentang kegiatan silaturahmi dengan tokoh-tokoh islam dan pondok pesantren, kebijakan pemerintah membuat hari santri nasional dan kebijakan haji, kerja sama antarnegara islam, serta peringatan hari-hari besar islam.

\section{REKOMENDASI}

Berkenaan dengan penelitian, peneliti menyarankan kepada masyarakat agar lebih kritis dalam melihat, memahami, dan menyikapi berita di media massa ataupun online termasuk setkab.go.id. Masyarakat diharapkan memahami literasi media. Peneliti juga menyarankan kepada humas pemerintah khususnya humas sekretariat kabinet agar memberikan kategori isu khusus di kolom website agar memudahkan pembaca dalam memilah kegiatan Presiden Jokowi. Penelitian ini menggunakan analisis framing model Robert N. Entman. Apabila pada penelitian selanjutnya ingin meneliti kembali dengan permasalahan yang sama, maka peneliti menyarankan untuk dapat menggunakan model framing Zhondang Pan dan Gerald M. Kosicki ataupun William Gamson. Selain itu peneliti selanjutnya dapat menggunakan teori yang berbeda seperti analisis isi atau teori media massa.

\section{DAFTAR PUSTAKA}

Damayanti, S., Mayangsari, I. D., \& Putra, D. K. S. (2016). Analisis framing robert n. Entman atas pemberitaan reklamasi teluk jakarta di majalah tempo. eProceedings of Management, 3(3).

Danesi, M. (2010). Pesan, tanda, dan makna. Yogyakarta: Jalasutra

Entman, R. (1993). Framing: Towards clarification of a fractured paradigm. Journal of Communication, 43 (4), 1993 , 51-58.

Eriyanto. (2009). Analisis framing: konstruksi, ideologi dan politik media. Yogyakarta: PT LKIS Pelangi Aksara.

Febriani, N. K. N., Cahyani, D. Y., \& Gelgel, N. M. R. A. (2016). Pembingkaian berita seratus hari kerja Jokowi-JK (Analisis framing program berita di metro hari ini). E-Jurnal Medium. Unud. ac. id, 25 
Flora, E. (2014). Analisis framing berita calon presiden RI 2014-2019 pada surat kabar Kaltim Post dan tribun Kaltim. Jurnal Ilmu Komunikasi Universitas Mulawarman, 2(3).

Khaerunnisya, R. (2012). Analisis framing pemberitaan kepengurusan pssi terkait format kompetisi liga indonesia 2011/2012 pada media. online goal.com. Diakses pada 27 Maret 2019, dari repository.unhas.ac.id/bitstream/ handle/.../Skripsi\%20Riska\%20Khaerunnisya.pdf?...1

Kriyantono, R. (2014). Teori public relations perspektif barat dan lokal aplikasi penelitian dan praktik. Jakarta: Kencana Prenada Media Group.

Kriyantono, R. (2015). Public relations \& crisis management: Pendekatan critical public relations etnografi kritis dan kualitatif. Jakarta: Kencana Prenada Media Group.

Miles, M. B., Huberman, A. M., \& Saldana, J. (2014). Qualitative data analysis: a Methods Sourcebook (3rd ed.). USA: Sage

Mulyana, D., \& Solatun. (2013). Metode penelitian komunikasi. Bandung: Remaja Rosdakarya.

Ningsih, N. W. (2013). Analisis framing pemberitaan penembakan solikin di harian jawa pos dan duta masyarakat. Jurnal e-Komunikasi, 1(1).

Prastya, N. M. (2016). Analisis framing dalam riset public relations. Jurnal nformasi: Kajian Ilmu Komunikasi, 46(2), 193-204.

Prastya, N. M. (2018). Analisis framing terhadap pernyataan resmi kemenpora ri dan pssi dalam kasus sanksi fifa terhadap indonesia. Jurnal Komunikator, 10(1), 10-23.

Prihananto, M. (2014). Participant observation dan personal documents dalam penelitian kualitatif BKI. Jurnal Bimbingan dan Konseling Islam, 2(1), 48-64.

Rich, C. (2010). Writing and Reporting News: A Coaching Method. United States of America: Wadsworth

Surbakti, L. J. R. (2013). Analisis framing pemberitaan konflik partai nasional demokrat (nasdem) di harian media indonesia dan koran sindo. Jurnal e-Komunikasi, 1(2).

Wiratama, M. H., \& Ati, H. D. L. (2017, November). Analisis berita donald trump dalam kampaye rasisme di cnn indonesia periode oktober 2016-februari 2017 (Model Analisis Framing Robert N. Entman). Seminar Nasional FISIP Unila 
